University of Rhode Island

DigitalCommons@URI

\title{
The Politics of Welfare Exclusion: Immigration and Disparity in Medicaid Coverage
}

Ling Zhu

Ping Xu

pingxu@uri.edu

Follow this and additional works at: https://digitalcommons.uri.edu/psc_facpubs

The University of Rhode Island Faculty have made this article openly available.

Please let us know how Open Access to this research benefits you.

This is a pre-publication author manuscript of the final, published article.

Terms of Use

This article is made available under the terms and conditions applicable towards Open Access

Policy Articles, as set forth in our Terms of Use.

Citation/Publisher Attribution

Zhu, L. and Xu, P. (2015), The Politics of Welfare Exclusion: Immigration and Disparity in Medicaid Coverage. Policy Stud J, 43: 456-483. doi:10.1111/psj.12106

Available at: http://onlinelibrary.wiley.com/doi/10.1111/psj.12106/abstract

This Article is brought to you for free and open access by the Political Science at DigitalCommons@URI. It has been accepted for inclusion in Political Science Faculty Publications by an authorized administrator of DigitalCommons@URI.For more information, please contact digitalcommons-group@uri.edu. 


\title{
The Politics of Welfare Exclusion: Immigration and Disparity in Medicaid Coverage
}

\author{
Ling Zhu \\ 436 PGH Hall \\ Department of Political Science \\ University of Houston \\ Houston, TX 77204 \\ lzhu4@central.uh.edu \\ and \\ Ping Xu \\ Department of Political Science \\ University of Rhode Island \\ Washburn Hall 80 Upper College Road, Suite 4 \\ Kingston, RI 02881-0817 \\ pingxu@uri.edu
}

\section{Acknowledgement}

An earlier version of this paper has been presented at the research symposium, "Minorities, Politics, and Health: A Symposium on Contemporary Health Disparities Research," Texas A\&M University, May 16-17, 2013. We thank Regina Branton, Valerie Martinez-Ebers, Kenneth J. Meier, Francisco I. Pedraza, and Rene Rocha for their perceptive comments on the earlier version of this paper. We thank Andrea Eckelman, Joseph Korzeb, Markie McBrayer, and Kenicia Wright for their excellent research assistance. We also thank the editors and three anonymous reviewers for their constructive feedback. All errors remain ours.

\begin{abstract}
The rapid growth of the immigrant population in the U.S., along with changes in the demographics and the political landscape, has often raised questions for understanding trends of inequality. Important issues that have received little scholarly attention thus far are excluding immigrants' social rights through decisive policy choices and the distributive consequences of such exclusive policies. In this paper, we examine how immigration and state policies on immigrants' access to safety net programs together influence social inequality in the context of health care. We analyze the combined effect of immigration population density and state immigrant Medicaid eligibility rules on the gap of Medicaid coverage rates between native- and foreign-born populations. When tracking inequality in Medicaid coverage and critical policy changes in the post-PRWORA era, we find that exclusive state policies widen the native-foreign Medicaid coverage gap. Moreover, the effect of state policies is conditional upon the size of the immigrant population in that state. Our findings suggest immigrants' formal integration into the welfare system is crucial for understanding social inequality in the U.S. states.
\end{abstract}

KEY WORDS: immigrant welfare eligibility, health care inequality, politics of exclusion 


\section{Introduction}

The United States stands alone from other industrialized democracies because of its longstanding political struggle over universal health care reforms (Starr, 2011). Among hundreds of thousands of workers who live without health insurance, America's newcomers- the immigrant population-face even more daunting situations. The Personal Responsibility and Work Opportunity Reconciliation Act (PRWORA) of 1996, along with the surge of anti-immigration sentiment among the masses, made it more difficult for immigrants and their children to obtain health care. According to the Census Bureau, the proportion of the foreign-born population without health care coverage was more than double the amount of native-born citizens (DeNavas-Walt, Proctor and Smith, 2011, 25). Immigration status, as Ku and Matani (2001) substantiate, has become "an important component of racial and ethnic disparities in insurance coverage and access to care (247)."

The ideological battle on the issue of immigration and immigrants' access to health care has its root in divided opinions about how the American democracy should integrate its newcomers. At the national level, political compartmentalization led to the Clinton welfare reform and substantial retrenchment of federal responsibility in providing health care to immigrant families. ${ }^{1}$ As such, much of the political stake was left to the states' discretion (Hero and Preuhs, 2007). The state-level picture, nevertheless, shows mixed promises: a few states have been successful in pushing forward new generous policies to qualify immigrants for Medicaid provisions, while others have followed the federal government and tightened their health care provisions to immigrants. To this end, the health care disparities confronting

1 According to the PRWORA (1996), immigrants entering the US after August 22, 1996 are barred from Medicaid and most other federal-funded welfare programs for the first five years after their entry. Besides Medicaid, immigrants are also barred from federal-funded food stamps, Supplemental Security Income, Temporary Assistance for Needy Families (TANF) benefits, and services provided through the Social Services Block Grant (SSBG). 
immigrants create a major normative dilemma: on the one hand, immigrants are an integral part of American society; on the other hand, they face more political barriers to being incorporated into the American welfare system. This normative dilemma has motivated an important research agenda in welfare state politics that deals with both immigration and social inequality.

Numerous prior studies have examined the relationship between immigration and welfare policy, much of which focuses on either how attitudes toward ethnic minorities influence public support for welfare (Gilens, 2000; Hainmuller and Hiscox, 2010; Martin, 2001), or on how immigration and ethnic diversity influence the generosity of welfare states (Agrawal, 2008; Borjas, 1999; Hero and Preuhs, 2007; Nannestad, 2007). Research has increasingly theorized that immigration-induced ethnic diversity is a challenge for sustaining generous welfare states. Yet, much fewer studies chart the distributive consequences of state policies that define immigrants' legal access to safety net programs. In this study, we take a different prism by focusing on the link between immigration, state policies, and social inequality in the context of health care. Our primary goal is to uncover how states' policy decisions in welfare inclusion/exclusion of immigrants influence inequality in health care coverage between immigrants and their nativeborn counterparts, and how such an effect is conditional upon the state environment for immigrants.

Our exploration of immigrants' welfare rights and the implications on social inequality hinges on a political exclusion perspective. We contend that the exclusion of immigrants from the welfare system at the subnational level enlarges the Medicaid coverage gap between the native- and foreign-born populations for two reasons. First, states use restrictive eligibility policies to formally exclude some immigrants from safety-net programs $(\mathrm{Ku}, 2009 \mathrm{a}$; Zimmermann and Fix, 1998). Second, exclusive policies create an icy policy environment that 
sends negative signals about the role of government, thus these policies produce negative social constructions for targeted populations and closely associated groups (Campbell, 2012; Schneider and Ingram, 1993; Soss and Schram, 2007) which discourages eligible immigrants from participating in safety net programs (Fix, 2009). Extending previous studies that only compare state-level immigrant welfare eligibilities in one year (Hero and Preuhs, 2007; Filindra, 2013), we offer the first systematic comparison of immigrant Medicaid eligibility rules across states and multiple years in the post-PRWORA era. We also use immigrant network theory to endorse a conditional effect of state immigrant welfare policies and the state-level immigrant population density on social inequality. We contend that the Medicaid coverage gap between immigrants and their native-born counterparts is larger in states with more exclusive policies, and this positive relationship between state policy exclusiveness and social inequality is strengthened in states with lower levels of immigrant population density.

We then empirically examine the combined effects of immigrant population density and state-level immigrant Medicaid eligibility rules on the native-foreign Medicaid coverage gap. The state-level panel data analysis shows support for both hypotheses. We find that states with inclusive Medicaid policies have lower levels of health care inequality than states with exclusive Medicaid policies. In addition, immigrant population density is also found to condition the relationship between state policies and disparities in Medicaid coverage. The native-foreign Medicaid coverage gap is seen as the greatest among those states with a relatively sparser immigrant population and very exclusive Medicaid policies, yet the gap is negligible in states with a denser immigrant population and inclusive immigrant Medicaid policies. Our research suggests that social inequality in the U.S. states cannot be fully understood without considering the politics of exclusion in policymaking and immigrant social network at the subnational level. 


\section{Immigration, Political Exclusion, and Social Inequality in Health Care}

The United States witnessed a substantial increase in immigration in the past few decades. According to the Census Bureau, in 1970, the United States had a foreign-born population of approximately 9.5 million; however, the number increased to 38 million in 2007, almost quadrupling from 1970 (Census 1999; 2007). ${ }^{2}$ This rapid demographic change coincides with the rising public concern regarding immigrants' use of public services, such as education, social assistance, and health care (Burns and Gimpel, 2000; Fix, 2009; Hainmuller and Hiscox, 2010). Exclusive welfare reforms at both the national and state level restricted immigrants' access to government funds that finance health insurance plans for low-income families. As a result, the gap in health insurance coverage between native- and foreign- born populations continues to grow (LaVeist, 2005). The nexus between immigration and social inequality in health care access has recently gained scholarly attention and offered a new basis for studying the implications of immigration on social equity. Various theoretical frameworks have been developed to probe the link between immigration and social inequality, and we focus on twothe politics of exclusion and the immigrant social network.

\section{Political Exclusion through Welfare Reform}

A growing body of literature finds that immigration has increased racial and ethnic complexity in American states and raised new challenges to sustaining generous social policy provisions (Miguel and Gugerty, 2005; Hero, 2010). The increasing race and ethnic diversity may dissolve social cohesion and reduce the generosity of safety net programs (Alesina, Glaeser and Sacerdote, 2001; Burns and Gimpel, 2000; Hero, 1998; Hero and Tolbert, 1998; Rowthorn,

2 In the United States, an immigrant normally refers to someone who obtains permanent residency. The term foreign-born population does not only include permanent residents, but also naturalized citizens, temporary legal foreign-born residents and undocumented immigrants. 
2008; Stichnothe and Van der Straete, 2011). Consistent with this social erosion argument is the group-competition and political exclusion argument. For example, Esses et al. (2001) assert that immigration in North America, to a large extent, has triggered perceived threats and groupcompetition among native-born populations. With such a symbolic threat, an in-group (e.g. native-born citizens) is likely to demand policies that restrict an out-group (e.g. immigrants) from accessing their material resources.

Indeed, the 1996 federal welfare reform was driven by a wave of strong anti-immigrant sentiment along with the resurgence of nativism after the passage of Proposition 187 in California (Agrawal 2008, Alvarez and Butterfield 2000). From 1982 to 1992, the United States witnessed the number of immigrant applicants for Supplemental Security Income (SSI) double in size. By 1992, the number of immigrant recipients rose to over 600,000 and accounted for more than $25 \%$ of the total number of recipients (House of Representatives Committee on Ways and Means, 1998). Both the American public and the federal government were concerned about such sharp increases in the volume of immigrant welfare recipients, as well as the possibility that immigrants might "bring in their parents ... with the intention of supporting them by taking advantage of the welfare benefits" (Committee on Ways and Means, 1998, 1398). Facing the increasing concerns that immigrants' consumption of social assistance may lead to a slew of problems threatening the resource pool for low-income citizens, Congress passed the PRWORA in 1996, which restricted immigrants from receiving federal-funded welfare benefits including Medicaid in the first five years after their entry. One negative consequence of excluding immigrants' welfare rights under the PRWORA is that it led to a substantial reduction in immigrants' participation in various safety net programs, including Medicaid. Ku and Papademtriou (2007) report that, since the enactment of the PRWORA, low-income non-citizens 
have had much lower Medicaid coverage rates than low-income citizens.

The federal-level reform gave states discretion to make complementary state welfare policies. For example, by using state funds, states can determine (1) whether or not to give legal immigrants who entered the United States before August 22, 1996 access to Medicaid, (2) whether or not immigrants who entered the United States after August 22, 1996 are eligible for Medicaid during the five-year bar, (3) whether or not immigrants who entered the United States after August 22, 1996 are eligible for Medicaid after the five-year bar, (4) whether or not to provide Medicaid to unqualified immigrants in the first five years after their entry, and (5) whether or not to have state funded health insurance programs for immigrants (Bitler and Hoynes, 2013). States differ in the making of their own immigrant Medicaid policies, with some strictly following the federal law without providing immigrants with any additional Medicaid coverage, and others using state funds to provide Medicaid coverage in all five aspects. For example, ever since 1996, Wyoming has strictly enforced the federal regulations and excluded immigrants from Medicaid. On the contrary, states like California, Massachusetts and Pennsylvania decided, immediately after the 1996 PRWORA, that they would use their own state funds to fund immigrants Medicaid in all of the above-mentioned aspects. Ever since then, they have been providing Medicaid to immigrants and treating them just like citizens.

More tellingly, exclusive state policies not only disqualify non-eligible immigrants’ access to safety net programs, but also discourage eligible immigrants from participating in social programs by producing negative policy feedback. Social construction theory (Schneider and Ingram 1993) suggests that specific public policy designs create positive or negative social constructions for the targeted populations. Such social constructions can directly influence the government's role in providing social welfare, and the targeted population's behavior of welfare 
participation. For instance, exclusive state policies create an icy policy environment for immigrants by attaching them with negative social labels, such as "being lazy", "undeserving", and "welfare magnet." Through such stigmatization, exclusive policies send negative signals about the role of government in the lives targeted, depressing eligible immigrants' participation in these policy programs.

As Hacker (2006) explains, in health care and other social policy areas, government often hesitates to directly provide social protection to the underclass, which sends "unwelcoming" signals to those who are negatively socially constructed. Other empirical studies show that subnational policies that are exclusive (or punitive) toward undocumented immigrants can have negative policy feedback (Campbell, 2012; Soss and Schram 2007) or the so-called "chilling effect" (Fix, 2010; Waston, 2014) on eligible immigrants' participation in safety-net programs. In their study of health-care services in immigrant communities in five metropolitan counties in Texas, Hagan et al. (2003) find that many eligible immigrants voluntarily withdrew from Medicaid after Texas followed the federal welfare reform and initiated exclusive immigrant eligibility rules for various state safety net programs. Other scholars who study welfare reform and immigrants' Medicaid enrollment report a similar "chilling effect" on non-citizens' Medicaid participation in more than one state (Bilter, Gelbach and Hoynes, 2005; Ellwood and $\mathrm{Ku}, 1998 ; \mathrm{Ku}, 2009 \mathrm{a})$. As Ku and Matani $(2001,247)$ describe, changes in welfare program eligibility rules constitute "an important component of racial and ethnic disparities in insurance coverage and access to care."

In sum, the underlying mechanism of the "chilling effect," explained by Hook (2003, 614), is that "because of immigrants' particularly vulnerable legal and social status, the immigrant-specific provisions of welfare reform may have increased immigrants' confusion 
about their eligibility for welfare benefits and heightened their distrust of the U.S. government." Tightening eligibility is conceptualized as an important source of the icy policy climate for immigrants (Fix, 2009; Potocky-Pripodi, 2004; Ku, 2009a,b). Considering that exclusive state welfare policies not only set legal barriers for immigrants' welfare participation but also cause a "chilling effect" and depress eligible immigrants' welfare participation, we expect the nativeforeign difference in Medicaid coverage to be larger in states with exclusive immigrant Medicaid eligibility rules than that in states with inclusive policies.

H1: States with exclusive immigrant Medicaid eligibility rules have a larger native-foreign Medicaid coverage gap, and vice versa.

\section{Immigrant Population Density as a Conditional State Context}

American states differ from one another in their stocks of immigrants as well as their immigration flows. Gateways such as California, New York, Florida, and Texas not only maintain a large foreign-born population, but also saw large amounts of immigration inflows in recent years. New destination states, such as Alabama, North Carolina and South Carolina, experienced large influxes of immigrants in the two most recent decades, although their foreignborn population stocks might not be as high. States such as West Virginia, Montana, Wyoming, Kentucky and Nebraska have exactly the opposite experience in immigration. Not only were their foreign-born population stocks low, immigration inflows to these states in recent years were also low. Both the existing immigrant population that resided in a state for a relatively long time period and the newcomers who arrived to a state recently formed important immigrant networks. These immigrant networks play an important role in welfare participation through two pathways: (1) reducing the stigma of welfare participation, and (2) information spillovers (Banerjee, 1992; Bikhchandani, Hirschleifer and Welch, 1992; Borjas, 1995; Case and Katz, 1991; Ellison and Fudenberg, 1993, 1995). Simply put, socializing with other immigrant welfare recipients will 
make individuals feel less shameful of taking welfare benefits. Meanwhile, immigrants are more likely to obtain more information about welfare programs in communities with strong immigrant social networks than in places where they are isolated.

Information spillovers through immigrants' social networks provide an important mechanism for immigrants to learn about welfare programs and eligibility rules. Such a mechanism is crucial for immigrants' welfare participation, because it is very common for immigrants not to know if they are eligible for welfare programs such as Medicaid in their state. Such blindness is due to a combination of factors. First, state welfare eligibility rules are often quite complicated and contain multiple aspects that could influence the eligibility of a particular immigrant. For example, immigration status, age, length of stay, and whether the first entry was before or after August 22, 1996 could all potentially influence an immigrant's eligibility for Medicaid in one way or another. Besides the complexity, eligibility rules also change over time and vary substantially across states. Many states have changed their immigrant eligibility rules more than once since 1996. Mastering the knowledge of the eligibility rules and keeping up with the changes is a challenging job to any immigrant individual. Last but not least, information on these immigrant welfare eligibility rules, supposedly all public information, is ironically publicly unavailable in a vast majority of the states. Indeed, we discover in our endeavor of data collection that few states publicize information on immigrant welfare eligibility rules on a public web site. We also discover from our email correspondence and phone conversations that officials in state Medicaid agencies who deal with Medicaid recipients on a daily basis do not always know the eligibility rules for immigrants in their own state.

The fact that immigrant welfare eligibility rules are complex and relevant public information is not readily available invites us to consider other factors in the policy-disparity 
mechanism. Even though welfare exclusion of immigrants plays an important role in state level native-foreign Medicaid coverage gaps, the working of such exclusion should depend upon the immigrant network. In states with a denser immigrant population, there is a much higher chance for an average immigrant to use the social network among fellow immigrants to learn about the eligibility rules and participate in welfare programs. In contrast, in states with a sparse immigrant population, immigrants struggle to obtain information from a social network of their own about how to participate in various welfare programs. Imagine if an individual migrates from the Philippines to the United States and wishes to participate in its welfare programs. Both California and Alaska have quite generous welfare policies toward immigrants, yet, the Filipino might have a much better chance to have contacts with his/her fellow immigrants, learn about the eligibility rules from the large immigrant population in California and jump on Medicaid as soon as conditions mature. In contrast, if the Filipino arrives to Alaska where there are few immigrants, it will possibly take him/her a much longer time to learn about the welfare eligibility rules or (s)he will never learn about them. Indeed, by using a micro sample from the Census data, Bertrand, Luttmer and Mullainathan (2000) find strong empirical evidence that immigrants who have more contacts with other immigrants, especially immigrants with knowledge of welfare programs, are much more likely to participate in welfare programs themselves. Aizer and Currie (2003) also find that the use of publicly funded prenatal care in California is highly correlated within race/ethnicity groups and neighborhoods (2574).

Alternatively, the size of immigrant population is also an important demographic factor that is indicative of immigrants' (especially Latinos') political mobilization and their influence in the policymaking process (Leighley 2001, Sanchez 2006). A large and strong immigrant population can positively influence how state-level political institutions deal with immigration- 
related social policy issues. Indeed, public opinion research shows Latinos are more attentive to immigration policies and have more liberal policy attitudes than non-Latino voters. Whether or not immigrants' (or Latinos') policy preferences are reflected in the actual policy making process depends on the level of their acculturation and how political elites respond to their policy interests (Branton 2007). In fact, previous research shows that political elites (such as legislators) are more likely to be responsive to immigrants' demands in states with a large immigrant (or Latino) population than states with a small immigrant population (Casellas 2009).

Considering that a large immigrant population will better provide a necessary social network for immigrant welfare participation and promote immigrants' influence on the policymaking process, we argue that the size of the immigrant population will condition the effect of state immigrant Medicaid policy on the foreign-native Medicaid coverage gap. A large existing immigrant population and a large immigration influx in recent years could both alleviate the negative impact of exclusive policies on social inequality, but a small immigrant population can deteriorate the negative effect of exclusive policies on social inequality.

H2: The positive effect of exclusive immigrant Medicaid policies on the native-foreign disparity in Medicaid coverage is strengthened in states with a sparser immigrant population or a slower growth in immigration population, but attenuated in states with a denser immigrant population or a faster growth in immigration population.

\section{Data and Methods}

We devise a cross-section-time-series design by pooling state-level data of the native-foreign difference in Medicaid coverage and state-level immigrant Medicaid eligibility rules from 1998 to 2010 .

The Native-Foreign Difference in Medicaid Coverage. We measure the native-foreign difference in Medicaid coverage based on data from the Census Bureau's March Current 
Population Surveys. We count the numbers of native-born and foreign-born who had Medicaid coverage in each year and state. We then convert the raw counts into participation rates by calculating the percentage of native-born and foreign-born enrolled in Medicaid based on their own population size, as shown in equation $(1) .^{3}$

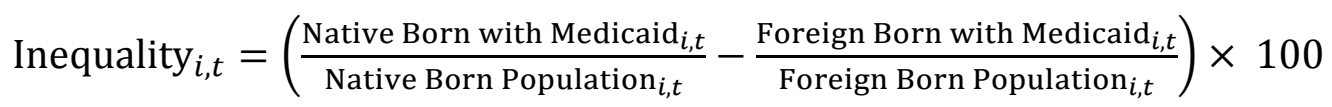

Figure 1 presents the cross-state and cross-year variation of the inequality measure. Overall, the net-difference between native-born and foreign-born individuals' Medicaid coverage does not change dramatically within states, but the between-state comparison is much sharper than within state differences. Figure 2 presents the ranking of American states based on their mean inequality scores from 1998 to 2010 . With only a few exceptions (Minnesota, Rhode Island, Massachusetts, and New York), most states have lower Medicaid coverage rates for their foreign-born residents. Nearly half of the states have large coverage gaps between native- and foreign-born residents that exceed $4 \%$.

\section{[Figure 1 About Here]}

[Figure 2 About Here]

Immigrant Medicaid Eligibility Score. Our first key explanatory variable "Immigrant Medicaid Eligibility Score" is an index measure of states' immigrant Medicaid eligibility rules in five specific areas. Specifically, we code the following five major eligibility rules for each state: (1) whether or not states grant Medicaid coverage to pre-PRWORA immigrants (i.e. immigrants who settled in the U.S. before August 22, 1996), (2) the availability of state funded Medicaid to 
post-PRWORA qualified immigrants during the five-year bar of federal benefits, (3) provision of Medicaid to post-PRWORA qualified immigrants after the five-year bar of federal benefits; (4) provision of Medicaid to certain unqualified immigrants for non-emergency medical care; (5) whether or not immigrants are eligible for state-only health insurance program for nonemergency medical care. A few prior studies provide snapshots of immigrants' Medicaid eligibilities (Bitler and Hoynes, 2013; Fortuny and Chaudry, 2011; Tumlin, Zimmermann and Ost, 1999), but not in all the years from 1998 to 2010. Our annual eligibility score measure is a compilation of these prior policy snapshots (Tumlin, Zimmermann and Ost, 1999) and our originally collected policy data through email and phone surveys of the 50 state Medicaid agencies. ${ }^{4}$ We code the first three eligibility items as "2" if all immigrants are eligible for Medicaid coverage, " 1 " if some immigrants are eligible, and " 0 " otherwise. We code the last two eligibility items as " 1 " if state-provided coverage is available to immigrants and " 0 " otherwise.

Because we code each eligibility item as a categorical variable, with arbitrarily assigned values (e.g. $0,1,2$, etc.), an additive scale will result in the first three eligibility items carrying more weight. Moreover, in order to capture more nuanced differences in states policies, we code the first three eligibility indicators by using a three-category ordinal scale, but the last two

4 Policy information regarding the 50 states in 1998 is collected from Tumlin, Zimmermann and Ost (1999)'s state policy snapshots of public benefits for immigrants. Fortuny and Chaudry (2011) provide a one-year policy snapshot for the 50 states in 2010. Bitler and Hoynes (2013) provide state Medicaid immigrant eligibility in 2002, 2004, 2005, 2006, 2007, and 2008 (see their Appendix Table 2). To cross validate policy information from multiple sources and to track policy changes in years between 1998 and 2010, we conducted a structured email/phone survey over the fifty state agencies (see Table 1). We sent email inquiries to each state agency, followed by one or multiple phone calls if we did not receive any email response from a state agency. In our structured email/phone survey, we asked state agencies to verify their current Medicaid immigrant eligibilities along the aforementioned five areas. We then asked state agencies to provide information about any policy change between 1998 and 2010 (i.e. whether there were any changes in immigrant Medicaid eligibility between 1998 and 2010; if so, what changes and when they took place). 
indicators are dichotomous. In other words, the five eligibility items are scaled differently, which is a problem for generating an additive score. Therefore, we adopt the Bayesian measurement approach developed by Kevin Quinn (2004) to deal with such mixed multivariate responses. Compared with a simple additive scale or the standard factor analysis, Quinn's Bayesian factor analysis approach has two advantages. First, the Bayesian factor analytical model produces a standardized policy index, which is converted based on the estimated factor loadings of the five eligibility items. Such a standardized index is invariant to the varying response scales of different eligibility items. In other words, the weight of each eligibility item in the index is defined by its (estimated) association with the underlying latent dimension of welfare inclusion, and is not defined by how it is coded. Second, the Bayesian approach does not estimate parameters in the measurement model as deterministic values but instead explicitly incorporates uncertainty in all parameters. Thus, the Bayesian approach helps to reduce measurement errors, and improves inferences about how states with extremely exclusive and inclusive policies would be placed on the latent scale of immigrant inclusion.

We compute the Bayesian factor index of immigrant inclusion using Kevin Quinn's (2004) R package MCMCpack, with 2,000 burn-in iterations and 200,000 MCMC scans after the burn-in. The resulting Bayesian factor index of immigrant inclusion has a range from -1.08 to 1.5, with a greater value indicating more inclusive state Medicaid eligibility rules toward immigrants. ${ }^{5}$ Figure 3 ranks the 50 states based on the mean-level of immigrant inclusion in their Medicaid program from 1998 to 2010.

\section{[Figure 3 About Here]}

\footnotetext{
5 In the Supporting Information, we present more details on our data collection procedure for the five policy items capturing states' Medicaid immigrant eligibility rules. We also present the R script used to compute the Bayesian factor index. As shown in our replication code, using Kevin Quinn's MCMCpack in R, implementing the Bayesian measurement model is as straightforward as implementing the standard factor analytical model.
} 
As Figure 3 shows, states such as Alabama, Arizona, South Dakota, Texas, and Wyoming are among those that have low levels of immigrant inclusion in their Medicaid programs. These states either do not use state funds to provide Medicaid to immigrants at all, or only provide Medicaid to immigrants under very extreme circumstances. States such as California, Illinois, Massachusetts, New York, Pennsylvania, and Washington are among those that have high levels of immigrant inclusion in their Medicaid programs. They either exempt the five-year waiting period, or at least fund immigrants with Medicaid after the five-year bar using state funds. A few of these states also use discretionary state funds to provide immigrants with special health insurance programs. A handful of states changed their immigrant Medicaid eligibility rules from 1998 to 2010. For example, Colorado, Connecticut, and Maine had a high level of immigrant inclusion in their Medicaid programs after the 1996 welfare reform, but became much more exclusive since 2008. States such as Delaware, Hawaii, and New York followed most of the federal restrictions in the late 1990s, but restored immigrants' Medicaid eligibility in recent years.

Immigrant Population Density. Our conditional independent variable immigration population density is measured as the percentage of foreign-born population out of total population in each state year. We have collected data from the Census Bureau Current Population Surveys Annual Social and Economic Supplements (CPS-ASEC).

Racial/Ethnic Diversity. In our empirical models, we include the racial/ethnic diversity of state population as a control variable. According to the "group competition and exclusion" thesis mentioned in section 2, racial diversity triggers perceived threat and group-competition among native-born citizens (Esses et al., 2001; Hero and Preuhs, 2007). As a consequence, native-born citizens might demand policies that restrict immigrants' access to public health care. Therefore, 
racial diversity is expected to be positively associated with the native-foreign difference in

Medicaid coverage. We measure racial and ethnic diversity based on the Blau Index (Blau, 1977;

Hero, 1998; Tolbert and Hero, 2001):

$$
\text { Diversity }_{i, t}=\left[1-\sum\left(p_{i, j, t}\right)^{2}\right] \times 100
$$

In equation (2), $i$ and $t$ index a specific state-year observation, $j$ indexes a particular racial and ethnic group, and $\mathrm{p}$ denotes the proportion of group $\mathrm{j}$ as a share in the total population. We accounted for five racial groups (white, Black, Hispanic, Asian, and others) and scale the diversity measure from perfect homogeneity (0) to perfect heterogeneity (100). ${ }^{6}$

Macroeconomic Factors. We include Unemployment and Poverty ${ }^{7}$ as two macroeconomic factors that affect government redistribution in general. Moreover, Union Density is considered as another labor-market factor that influences state-level redistributive politics, including inequality in health care. Considering union's pro-immigrant attitudes in recent history, we argue that the union should reduce social inequality between immigrants and native-born citizens. This variable measures the percentage of wage and salary employees who are labor union members. Data for all three socioeconomic variables are drawn from the U.S. Census Bureau's Current Population Surveys.

Political Contexts. We include a set of state-level political variables to control for

\footnotetext{
6 Because the Diversity index is computed by counting states' Hispanic and Asian population, it has a positive correlation with the Immigration variable. To make sure that our key result pertaining to Immigration is not affected by the correlation between these two variables, we run a robustness check by replacing Diversity with \% Black Population. We obtain comparable results in models using \% Black Population. Moreover, with the consideration that different ethnic minority groups may have different preferences on social and immigration issues, we reestimate the empirical models by replacing the Diversity index by \% Black, Hispanic, and Asian populations. This alternative model specification does not alter the substantive findings regarding how Immigration and Eligibility interactively affect the native-foreign Medicaid coverage gap. See more details in the Supporting Information. 7 Because we focus on comparing the native- and foreign-born Medicaid coverage rates, it is conceivable that the relative poverty rates between these two groups rather than the overall poverty rates may have an impact. In the Supporting Information, we re-estimate the empirical models using two native-foreign relative poverty measures to replace the overall Poverty variable reported in the manuscript. The first relative poverty measure captures the net difference between poverty rates for foreign- and native-born population. The second relative poverty measure is the ratio of foreign-native poverty rates. Using these two relative poverty measures does not alter our key substantive findings.
} 
different political contexts. First, we control for mass liberalism, because prior studies suggest voters' liberal-conservative orientation affects the politics of immigration (Monogan, 2013), welfare generosity toward immigrants (Hero and Preuhs, 2007), and the overall welfare generosity (Erikson, Wright and McIver, 1993). We expect to see a negative association between mass liberalism and the native-foreign difference in Medicaid coverage. The Mass Liberalism variable is the Pacheco (2011) measure of the share of voters who identify with a liberal ideology orientation. In additional to Mass Liberalism, we also include the Berry et al. (1998) measure of Government Liberalism in our empirical models.

Second, we control for governor's partisanship. According to Bartels (2008), the partisanship of political executives has an influence on inequality. More specifically, Democratic presidents tend to prevent inequality from growing, while Republican presidents do not care about inequality as much, and therefore, inequality levels tend to increase under Republican presidents. Since our analysis is at the state level, we borrow Bartels' "political executives' partisanship and inequality" thesis, and argue that the partisanship of a political executive also influences social inequality levels at the state level. Therefore, the gap of Medicaid coverage between native- and foreign-born should be smaller in states with Democratic governors compared to states with Republican governors.

Third, we include the percentage of Democrats in state legislatures. Numerous scholars have examined the link between the partisan balance of state legislatures with welfare generosity, and they often connect left-wing partisanship with more redistribution, because left-wing parties mainly draw their support from the working class, who favor generous welfare spending (Hibbs, 1977; Tufte, 1980; Bradley et al., 2003; Bartels, 2008). On the other hand, right wing parties are often times linked with low levels of support for welfare spending and high levels of inequality 
(Hibbs, 1977; Tufte, 1980; Bradley et al., 2003; Bartels, 2008). Based on this contention, we argue that the percentage of Democrats in state legislatures is negatively associated with inequality in health care between native- and foreign-born populations. Data on these two variables are collected from Kapeluck and Garand (2011). ${ }^{8,9}$

Lastly, we include a dummy variable for southern states, because southern states have unique historical, political and cultural characteristics that differentiate them from other states (Key, 1949). Including the southern-dummy variable also helps to control for other unobserved policy factors, such as the emerging trend of adopting anti-immigration laws and aggressive local immigration enforcement in southern states (Rocha et al. 2014). We expect to see southern states to have greater social inequality.

Model Specification. Because we pooled data from fifty states and fifteen years, we consider both cross-state heterogeneity and time dependence in the pooled CSTS analysis (Beck and Katz, 1996; Beck, 2001). To deal with both heterogeneity and contemporaneous correlation across states, we implemented the Panel-Corrected -Standard-Error procedure (PCSE) proposed by Beck and Katz (1996). In addition, an AR(1) error specification is applied to the panel model to correct for serially auto-correlated disturbance terms. Based on the analysis of residuals, we identified a handful of state-year cases that provide unreliable data on the foreign-born Medicaid coverage rates. When mapping these state-year cases into the CPS sample, we see that they are all state-year cases, whereby the CPS sample suffers from small-population sampling errors for

\footnotetext{
8 Nebraska has a non-partisan state legislature, we proximate the Democratic Seat Share variable for Nebraska using Census Bureau's biannual data on vote cast for US Representatives by major political parties. As such, Nebraska is not excluded from the empirical analysis.

9 Both the immigrant population density variable and the set of state-level political variables included in our model might be correlated with state Medicaid eligibility rules for immigrants. To make sure that multicollinearity is not a concern, we check the variance inflation factor (VIF) statistics after estimating an OLS baseline model including all the explanatory variables. We do not detect troublesome VIF statistics. The mean VIF is 2.72. The VIF statistics associated with Immigration and Eligibility are 3.09 and 2.13, respectively. Government Liberalism is associated with the highest VIF score, 5.82. Including and excluding Government Liberalism do not alter findings pertaining to Immigration and Eligibility.
} 
the foreign-born population. We dropped these unreliable state-year cases from the empirical models reported in the paper. ${ }^{10}$

The potential endogenous relationship between the size of the foreign-born population and native-foreign differences in Medicaid coverage is another important issue that we are concerned with. Prior studies have reported that immigrants tend to cluster in states with generous welfare benefits (Borjas, Bronars and Trejo, 1992; Borjas, 1999; Frey et al., 1996), ${ }^{11}$ or in states where their relative economic opportunity and access to welfare resources are better (Hero, 1998). If the endogenous selection presents, the relationship between immigration and native-foreign differences in Medicaid coverage may not be static.

Instead, there could be a long-run relationship between the two variables. With our panel data, we do observe a weakly endogenous relationship between immigration and relative Medicaid inclusion of immigrants. Regressing Immigration $_{t}$ on Inequality $_{t}$ produces a negative

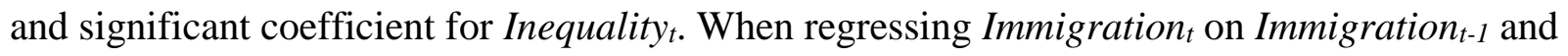
Inequality $_{t-1}$, we obtain an insignificant coefficient for Immigration Im $_{t-1}$. When regressing Inequality $_{t}$ on Inequality In- $_{\text {and }}$ Immigration ${ }_{t-1}$, we obtain a significant coefficient for Immigration $_{t-1}$. The more complex dynamics suggest that the stock of immigrants and the level of inequality in Medicaid coverage may share a long-run equilibrium relationship. In other words, changes in immigration and changes in the native-foreign Medicaid coverage gap may adjust to each other over time. Other scholars, who use alternative datasets to study immigration and welfare provision, also find a similar dynamic relationship (Lipsmeyer and Zhu 2011).

10 In the Supporting Information, we report empirical models without excluding these unreliable cases. The robustness check demonstrates that models excluding these reliable cases produce tighter results than those based on the full sample. Our substantive conclusions regarding the impact of immigration and states' immigrant Medicaid eligibility score, however, remain the same.

11 Some recent studies show that immigrants' location choice might not just be determined by the generosity of state welfare policies. For instance, Kaushal (2005) used the INS immigration data and found that immigrants' access to means-tested programs (TANF, food stamps, and Medicaid) has little impact on newcomers' location choice. 
To depict the long-run dynamic relationship, we added an error-correction specification in our model, following the econometric theories contributed by Engle and Granger (1991) and Banerjee et al. (1999). For the sake of parsimony, we specified the generalized one-step error correction model (De Boef, 2001; De Boef and Keele, 2008). The dynamic component is written as equation (3), in which $i$ and $t$ index state and year; $\beta$ denotes the vector of coefficients corresponding to all the control variables; and $\mathrm{X}$ denotes the vector of control variables. In the subsequent section, we report both the static and dynamic models and discuss our key findings primarily based on the error correction model.

$$
\begin{gathered}
\Delta \text { Inequality }_{i, t}=\alpha_{0}+\alpha_{1} \text { Inequality }_{i, t-1}+\alpha_{2} \text { Immigration }_{i, t-1}+\alpha_{3} \Delta \text { Immigration }_{i, t} \\
+\alpha_{4} \text { Eligibility }_{i, t}+\alpha_{5} \text { Immigration }_{i, t-1} \times \text { Eligibility }_{i, t}+\alpha_{6} \text { Immigration }_{i, t} \times \text { Eligibility }_{i, t}+ \\
\beta X_{i, t}+\varepsilon_{i, t}
\end{gathered}
$$

\section{Findings}

Table 1 reports our main statistical results. Model (1) in Table 1 shows the static interaction model. Model (2) in Table 1 presents findings based on the error-correction specification. Despite the biased estimations in Model (1), both models report consistent signs of all explanatory variables. In both models, the linear term of Eligibility ${ }_{t}$ Immigrant Medicaid Eligibility Score has a negative and significant coefficient $(b=-2.116, \mathrm{SE}=0.510$ in Model $(1) ; \mathrm{b}=$ -1.273, $\mathrm{SE}=0.365$ in Model (2)). The interaction terms in both models are positive and significant. Overall, we find support for the hypotheses that immigrant population density and states' immigrant Medicaid eligibility rules interactively shape the native-foreign Medicaid coverage gap. ${ }^{12}$

12 In our empirical analysis, we group foreign-born naturalized citizens and foreign-born non-citizens into one category and compare their Medicaid coverage with native-born citizens. Because both citizenship status and nativity may shape the political exclusion of immigrants, we analyze two additional "gap" measures--the Medicaid 
[Table 1 About Here]

The significant coefficients in both Models (1) and (2) mean that the effect of states' immigrant eligibility policies is conditional upon the immigrant population density within that state. Because coefficients in an interaction model are difficult for direct interpretation, we use Figure 4 to show the marginal effects of Immigrant Medicaid Eligibility Score conditional upon the two immigration variables (Brambor, Clark and Golder, 2006). Since the error-correction model is more appropriate than the static model in depicting the relationship between state policy, immigrant population density and inequality in Medicaid coverage, we generate Figure 4 based on Model (2).

\section{[Figure 4 About Here]}

Figure 4a shows the marginal effect of Immigrant Medicaid Eligibility Score conditional upon the immigrant population density in the previous year. We observe that in states with sparser immigrant populations, state Medicaid eligibility restrictions have negative and significant marginal effects on the native-foreign difference in Medicaid coverage. This negative marginal effect, however, is attenuated as the immigrant population density increases and cannot be statistically differentiated from zero in states with a very dense immigrant population

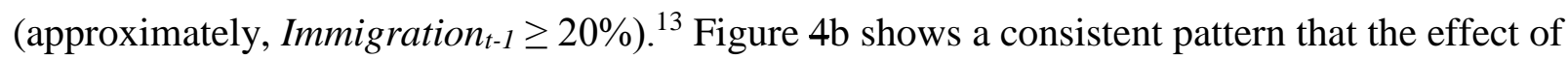

coverage gap between citizens and non-citizens, and the Medicaid coverage gap between native-born citizens and naturalized citizens. The comparison between native-born citizens and naturalized citizens would be a stricter test of our hypotheses, because naturalized citizens enjoy the similar citizen privilege as native-born citizens under PRWORA. Using these two alternative "gap" measures, we still reach similar substantive conclusions. We report these additional analyses in the Supporting Information. Ideally, we would also like to analyze Medicaid coverage rates for undocumented immigrants. To do so, we not only need reliable state-level estimation of the undocumented immigrant population, but also need individual-level records for how many undocumented immigrants are enrolled in Medicaid. The CPS data we use in this paper does not provide information on immigrants' legal status, therefore, we cannot separate undocumented immigrants from other immigrants in our analysis.

${ }^{13}$ Our data show that states such as California, New York and New Jersey (2005-2010) have more than 20\% foreign-born population and quite inclusive immigrant Medicaid eligibility rules; states such as Florida (2004-2010) and Nevada (2007-2010) have large stocks of foreign-born population (>20\%) and quite exclusive immigrant Medicaid eligibility rules. Since our data on foreign-born population are estimations based on the Current Population Surveys Annual Social and Economic Supplements, it is possible that foreign-born population estimation 
Immigrant Medicaid Eligibility Score is conditional upon the annual change of states' immigrant population density. The negative effect of Immigrant Medicaid Eligibility Score is strengthened in states that experienced decreases in foreign-born population density; yet, it is attenuated in states with a large increase in foreign-born population density. The marginal effect of state policies is not statistically differentiable from zero in states with a large influx of foreign-born population (approximately, $\Delta$ Immigration $_{t} \geq 2 \%$ ). These findings, taken together, support $H 2$.

The conditional hypothesis also implies a symmetric nature of the posited interaction relationship-when the effect of Immigrant Medicaid Eligibility Score on native-foreign Medicaid coverage gap is conditional upon immigrant population density, the effect of immigrant population density must be conditional upon the value of Immigrant Medicaid Eligibility Score (Berry, Golder and Milton, 2012). Therefore, to gauge empirical evidence for $\mathrm{H} 2$, we further examine whether both the short-run and long-run effects of immigration differ across the value of Immigrant Medicaid Eligibility Score in Figure 5 and Figure 6.

[Figure 5 About Here]

In equation (3), the coefficient of Immigration $_{t-1}\left(\alpha_{2}\right)$ represents the immediate changes in inequality associated with a one-unit change in immigration in year $t-1$, when Immigrant Medicaid Eligibility Score equals zero. The coefficient for Immigration $_{t-1} \times$ Eligibility, $_{5}$, represents how the immediate impact of Immigration $_{t-1}$ is conditional upon Immigrant Medicaid Eligibility Score. We substantively illustrate this conditional effect in Figure 5a. This interaction figure is generated for two different policy scenarios: exclusive and inclusive state Medicaid policy, by setting Eligibilityt at its 10th (exclusive states) and 90th (inclusive states) percentiles. We use the Clarify program (Tomz, Wittenberg and King, 2003) to simulate the mean predicted in Florida and Nevada was around $19 \%$ and $19.5 \%$, respectively. 
changes in the native-foreign Medicaid coverage gap across the full range of values observed for Immigration $_{t-1}$, holding all the other control variables constant. Figure 5a shows that the effect of Immigration $_{t^{-l}}$ differs in states with inclusive and exclusive Medicaid policies. When the percentage of foreign-born population is between $0 \%$ and $11 \%$ in the previous year, predicted changes in the native-foreign Medicaid coverage gap is always positive in exclusive states, but equal to zero in inclusive states. Overall, when the immigrant population density is high, immigration is associated with diminishing inequality.

Using the same method, Figure $5 b$ shows the predicted changes in inequality along the full range of $\Delta$ Immigration $_{t}$, in exclusive and inclusive states. This conditional short-run effect of $\Delta$ Immigration $_{t}$ is reflected by $\alpha_{3}$ and $\alpha_{6}$ in equation (3). In Figure $5 \mathrm{~b}$, we observe a negative and significant relationship between $\Delta$ Inequality $_{t}$ and $\Delta$ Immigration $_{t}$ in states with exclusive immigrant Medicaid eligibility policies, but not in states with inclusive policies. Figure 5 provides consistent evidence supporting $H 2$.

The error-correction model also specifies a long-run equilibrium relationship between immigration and inequality, conditional upon states' Medicaid policies. This long-run relationship means that an increase in immigration disrupts the underlying equilibrium, causing inequality to be too high. Therefore, when Immigrant Medicaid Eligibility Score equals zero, the inequality measure will respond by decreasing a total of 0.262 points (i.e. $\frac{\alpha_{2}}{-\alpha_{1}}$, see De Boef and Keele (2008)), spread over future time periods at a rate of $61.4 \%$ (i.e. $\alpha_{1}$ ) per time period. Further considering the conditional nature of the long-run effect, we use Figure 6 to compare the simulated long-run effect of immigration in exclusive and inclusive states, and how that long-run effect is distributed across future time periods. ${ }^{14}$

14 Similar to Figure 5, we also use the Clarify program in STATA12 to simulate the conditional long-run effect of 
[Figure 6 About Here]

We observe different long-run effects of immigration conditional upon the value of Immigrant Medicaid Eligibility Score. When Immigrant Medicaid Eligibility Score is low (exclusive policies), the estimated total long-run effect of immigration is approximately -0.334 . This long-run effect is statistically differentiable from zero (shown in Figure 6a), and distributed across subsequent four years at a rate of $61.4 \%$ per year. This means that a $1 \%$ increase in foreign-born population leads inequality to decrease a total of 0.334 points in a five-year period. When Immigrant Medicaid Eligibility Score is high, however, the mean estimated total long-run effect of immigration becomes much smaller (approximately -0.129), but its $95 \%$ confidence intervals overlap with zero. It is only distributed through the subsequent two years. We observe different long-run dynamics in exclusive and inclusive states, which provides additional support for $H 2$.

Results on the socioeconomic variables show the expected relationships. Both racial/ethnic diversity of the state population and poverty are positively associated with the native-foreign Medicaid coverage gap. Union density, however, is found to be negatively associated with the dependent variable. In addition, inequality in Medicaid coverage is lower in states with more Democratic legislators.

To summarize, our empirical findings underpin the interactive relationship between immigration and states' immigrant Medicaid eligibility policies. Exclusive state Medicaid policies widen the participation gap between the native- and foreign-born populations. Immigrant population, as an important state context, can change dynamically. It does not just condition the effect of state policy in a static way. In both the short- and long-run, the two factors have a 
salient combined effect on the native-foreign Medicaid coverage gap. In states with exclusive Medicaid policies and a small immigrant population, immigration leads to increases in the participation gap. In states with inclusive Medicaid policy and a small immigrant population, immigration does not lead to future changes in the participation gap. In states with a large immigrant population, immigration leads to decreases in social inequality no matter what the state Medicaid policy is.

\section{Concluding Discussions}

In this paper, we examine the relationship between state immigrant welfare policy, immigrant population density, and the native-foreign disparity in Medicaid coverage. This project contributes to previous literature in two important ways. Firstly, for the first time we have collected original data on state immigrant Medicaid eligibility rules across 50 states and over 13 years. Secondly, we have extended the literature on immigration and welfare provision by exploring a more complex relationship between state policies, immigration and the relative wellbeing of immigrants. We maintain that state policies, which include or exclude certain groups' social rights, are crucial determinants of the relative wellbeing of these groups.

In this paper, we develop two hypotheses based on the theories of the politics of welfare exclusion and social networks. Our first hypothesis centers on the political exclusion argument, and remains that while exclusive immigrant welfare policy leaves immigrants behind, inclusive immigrant welfare policy could reduce health care disparities. Our second hypothesis further posits a more complex relationship regarding how immigrant population density conditions the effect of state Medicaid policies on social inequality between immigrants and native-born residents. The results of our dynamic model lend support to both hypotheses. The state immigrant Medicaid eligibility score has a negative marginal effect on native-foreign Medicaid 
coverage gap in states with a low or moderate level of immigrant population density. The nativeforeign participation gap is the highest in states with both exclusive immigrant welfare policies and sparse immigrant populations. Moreover, immigration density and states' decisive policy choices interactively determine how Medicaid coverage is distributed among native-born and foreign-born residents. The interactive effects are seen both in the short-run and in the long-run. On the one hand, the marginal effect of state immigrant Medicaid eligibility score is conditional upon the size of foreign-born population in that state. On the other hand, state Medicaid eligibilities matter substantially in conditioning the effect of immigration from both the shortand long-run.

Although our findings suggest that the size of states' immigrant population has a measurable impact on immigrants' relative access to Medicaid, we admit that it is neither the only nor the perfect measure for the strength of immigrants' social networks. As some recent studies show, in-group heterogeneity based on immigrants' country of origin or legal status (e.g. citizens vs. noncitizens, immigrant workers vs. refugees/asylees, etc.) (Rocha and Matsubayashi 2014) as well as the residential segregation between immigrants and citizens (Rocha and Espino 2010), may be other important contextual factors that could shape the strength of immigrants' social networks and condition the relationship between state policies and social inequality. A natural extension of our research would be to further explore alternative approaches to operationalize the concept of immigrant social network along these lines.

Our research shows that states are important stakeholders when it comes to health care equality. As the Supreme Court has upheld the Patient Protection and Affordable Care Act of 2010, states will again be considered as pivotal stakeholders for policy implementation of health care reform in the near future. How could the American health care system be transformed to 
better incorporate its newcomers? Perhaps, the answer is more about bottom-up reforms from the states and less about the polarized political struggle at the national level.

To conclude, focusing on the social inequality aspect, we have explored the intersection of two problematic domains of the American democracy-immigration and health care. Our findings point toward a more complex relationship between immigration and social inequality in public health care provision. We show that the vulnerable group's (immigrants) relative wellbeing in a plural society hinges on a complex set of factors including its own group size, policy setups that define who are the "deserving" constituents, and the connection between socio-economic and political factors. Although providing everyone who is pursuing the "American dream" in the United States equal access to health care remains to be an "American struggle," the state-level picture presented here seems to shed some light on a future promise. So far, about half of the states have provided solely state funded health coverage to foreign-born residents and different strategies have been used to reduce eligibility restrictions to immigrants' access to health care. These inclusive policies help close the health care coverage gap between vulnerable immigrants and their citizen counterparts. Surprisingly, our research is one of the few systematic studies examining state-level immigrant welfare eligibility rules and its effect on social outcomes over time. Of course, Medicaid is only one of many welfare programs that are co-sponsored by the federal and state governments. Given that such policies have important implications on social equity in relation to over 40 million immigrants in the United States, scholars are encouraged to explore various state-level immigrant welfare policies, as well as their social and political implications on the quality of American democracy. 


\section{References}

Agrawal, Shantanu. 2008. "Immigrant Exclusion form Welfare: An Analysis of the 1996 Welfare Reform Legislative Process.” Politics and Policy 36(4): 636-75.

Aizer, Anne and Janet Currie. 2003. "Networks or Neighborhoods? Correlations in the Use of Publicly-Funded Maternity Care in California." Journal of Public Economics 88(12): 257385 .

Alesina, Alberto, Edward Glaeser and Bruce Sacerdote. 2001. "Why Doesn't the United States Have a European-Style Welfare States?” Brookings Papers on Economic Activity 2:187-254.

Alvarez, R. Michael and Tara L. Butterfield. 2000. "The Resurgence of Nativism in California: The Case of Proposition 187 and Illegal Immigration.” Social Science Quarterly 81(1): 16779.

Banerjee, Anindya. 1992. "A Simple Model of Hard Behavior." Quarterly Journal of Economics 107(3): 797-818.

Banerjee, Anindya, Juan Dolado, John. W. Galbraith and David F. Henry. 1999. Co-integration, Error-Correction, and the Economic Analysis of Non-Stationary Data. Oxford, UK: Oxford University Press.

Bartels, Larry. 2008. Unequal Democracy: The Political Economy of the New Gilded Age. New Jersey: Princeton University Press.

Beck, Nathaniel. 2001. "Time-Series-Cross-Section Data: What Have We Learned in the Past Few Years?" Annual Review of Political Science 4:271-93.

Beck, Nathaniel and Jonathan N. Katz. 1996. "Nuisance versus Substance: Specifying and Estimating Time-Series Cross-Section Models.” Political Analysis 6(1):1-36.

Berry, William D., Evan J. Ringquist, Richard C. Fording and Russell L. Hanson. 1998. "Measuring Citizen and Government Ideology in the American States:1960-93." American Journal of Political Science 42(1):327-48.

Berry, William D., Matt Golder and Naniel Milton. 2012. "Improving Tests of Theories Positing Interaction." Journal of Politics 74(3):653-71.

Bertrand, Marianne, Erzo F.P. Luttmer and Sendhil Mullainathan. 2000. "Network Effects and Welfare Cultures.” Quarterly Journal of Economics 115(3):1019-55.

Bikhchandani, Sushil, David Hirschleifer and Ivo Welch. 1992. "A Theory of Fads, Fashion, Custom, and Cultural Changes in Informational Cascades." Journal of Political Economy 100(5): 992-1126.

Bilter, Marianne P., Jonah B. Gelbach and Hilary W. Hoynes. 2005. "Welfare Reform and Health." The Journal of Human Resources 40(2): 309-34.

Bitler, Marianne P. and Hilary W. Hoynes. 2013. "Immigrants, Welfare Reform, and the U.S. Safety Net." In Immigration, Poverty, and Socioeconomic Inequality, ed. David Card and Steven Raphael. New York, NY: Russell Sage Foundation pp. 315-380.

Blau, Peter M. 1977. Inequality and Heterogeneity: A Primitive Theory of Social Structure. New York, NY: Free Press. 
Borjas, George J. 1995. "Ethnicity, Neighborhoods, and Human-Capital Externalities.” American Economic Review 85(3): 365-90.

Borjas, George J. 1999. “Immigration and Welfare Magnets.” Labor Economics 17(4):607-37.

Borjas, George J., Stephen G. Bronars and Stephen J. Trejo. 1992. "Self-Selection and Internal Migration in the United States.” Journal of Urban Economics 32(2):159-85.

Bradley, David, Evelyne Huber, Stephanie Moller, Francois Nielsen and John Stephens. 2003. "Distribution and Redistribution in Post-industrial Democracies." World Politics 55(2):193228.

Brambor, Thomas, William Roberts Clark and Matt Golder. 2006. "Understanding Interaction Models: Improving Empirical Analyses.” Political Analysis 14(1):63-82.

Branton, Regina. 2007. "Latino Attitudes toward Various Areas of Public Policy: The Importance of Acculturation.” Political Research Quarterly 60 (2): 293-303.

Burns, Peter and James G. Gimpel. 2000. "Economic Insecurity, Prejudicial Stereotypes, and Public Opinion in Immigration Policy." Political Science Quarterly 115(2): 201-25.

Campbell, Andrea. 2012. "Policy Makes Mass Politics." Annual Review of Political Science 15: 333-351.

Casellas, Jason P. 2009. “The Institutional and Demographic Determinants of Latino Representation." Legislative Studies Quarterly 34(3): 399-426.

Case, Anne C. and Laurence F. Katz. 1991. "The Company You Keep: The Effects of Family and Neighborhood on Disadvantaged Youths." National Bureau of Economic Research Working Paper: 3705.

Census. 1999. Nativity of Population, for Regions, Division, and States:1850-1990. Technical report U.S. Bureau of the Census.

Census. 2007. American Community Survey: Place of Birth by Citizenship Status; Year of Entry by Citizenship Status. Technical report U.S. Bureau of the Census.

De Boef, Suzanna. 2001. "Modeling Equilibrium Relationships: Error Correction Models with Strongly Autoregressive Data." Political Analysis 9(1):78-94.

De Boef, Suzanna and Luke Keele. 2008. "Taking Time Seriously.” American Journal of Political Science 52(1):184-200.

DeNavas-Walt, Carmen, Bernadette D. Proctor and Jessica C. Smith. 2011. "Income, Poverty, and Health Insurance Coverage in the United States:2010.” Department of Commerce.

Ellison, Glenn and Drew Fudenberg. 1993. "Rules of Thumb for Social Learning." Journal of Political Economy 101(4):612-43.

Ellison, Glenn and Drew Fudenberg. 1995. "Word-of-Mouth Communication and Social Learning.” Quarterly Journal of Economics 110(1):93-126.

Ellwood, Marilyn R. and Leighton Ku. 1998. "Welfare and Immigration Reforms: Unintended Side Effects for Medicaid." Health Affairs 17(3):137-51.

Engle, Robert. F. and Clive W.J. Granger. 1991. "Co-integration and Error Correction: Representation, Estimation, and Testing." In Long-Run Economic Relationships: Readings 
in Co-integration, ed. Robert. F. Engle and Clive W.J. Granger. Oxford, UK: Oxford University Press, 81-111.

Erikson, Robert S., Gerald C. Wright and John P. McIver. 1993. Statehouse Democracy: Public Opinion and Policy in the American States. New York, NY: Cambridge University Press.

Esses, Victoria M., John F. Dovidio, Lynne M. Jackson and Tamara L. Armstrong. 2001. “The Immigration Dilemma: the Role of Perceived Group Competition, Ethnic Prejudice and National Identity." Journal of Social Issues 57(3):389-412.

Filindra, Alexandra. 2013. "Immigration Social Policy in the American States: Race Politics and State TANF and Medicaid Eligibility Rules for Legal Permanent Residents.” State Politics \& Policy Quarterly 13(1):26-48.

Fix, Michael. 2009. Immigrants and Welfare: the Impact of Welfare Reform on American's Newcomers. New York: Russell Sage Foundation.

Fortuny, Karina and Ajay Chaudry. 2011. "A Comprehensive Review of Immigrant Access to Health and Human Services".

Frey, William H., Kao-Lee Liaw, Yu Xie and Marcia J. Carlson. 1996. "Interstate Migration of the US Poverty Population: Immigration 'Pushes and Welfare Magnet Pulls'.” Population and Environment 17(6):491-533.

Gilens, Martin. 2000. Why Americans Hate Welfare: Race, Media and the Politics of Antipoverty Policy. Chicago, IL: The University of Chicago Press.

Hacker, Jacob. 2006. The Great Risk Shift: The New Economic Insecurity and the Decline of the American Dream. New York, NY: Oxford University Press.

Hagan, Jacqueline, Nestor Rodriguez, Randy Capps and Nika Kabiri. 2003. "The Effects of Recent Welfare and Immigration Reforms on Immigrants' Access to Health Care." International Migration Review 37(2):444-63.

Hainmuller, Jens and Michael J. Hiscox. 2010. "Attitudes toward Highly Skilled and Lowskilled Immigration: Evidence from a Survey Experiment.” American Political Science Review 104(1):61-84.

Hero, Rodney E. 1998. Faces of Inequality: Social Diversity in American Politics. New York, NY: Oxford University Press.

Hero, Rodney E. 2010. "Immigration and Social Policy in the United States." Annual Review of Political Science 13:445-68.

Hero, Rodney E. and Caroline J. Tolbert. 1998. "A Racial/Ethnic Diversity Interpretation of Politics and Policy in the States of the U.S.” Journal of Politics 40(3):851-71.

Hero, Rodney E. and Robert R. Preuhs. 2007. "Immigration and the Evolving American Welfare State: Examining Policies in the U.S. States." American Journal of Political Science 51(3):498-517.

Hibbs, Douglas A. Jr. 1977. "Political Parties and Macroeconomic Policy." American Political Science Review 71(4):1467-87.

Hook, Jennifer Van. 2003. "Welfare Reform's Chilling Effects on Noncitizens: Changes in Noncitizen Welfare Recipiency or Shifts in Citizenship Status." Social Science Quarterly 


$$
\text { 84(3):613-31. }
$$

Kapeluck, Branwell Dubose and James C. Garand. 2011. "Explaining the Size of Government in the American States: A Pooled Analysis, 1960-2004." Updated dataset based on the dataset from this article.

Kaushal, Neeraj. 2005. "New Immigrants' Location Choices: Magnets without Welfare." Journal of Labor Economics 23(1): 59-80.

Key, V.O., Jr. 1949. Southern Politics in State and Nation. Knoxville, TN:University of Tennessee Press.

$\mathrm{Ku}$, Leighton. 2009a. Changes in Immigrants' Use of Medicaid and Food Stamps: The Role of Eligibility and Other Factors. In Immigrants and Welfare: the Impact of Welfare Reform on American's Newcomers, ed. Michael Fix. New Haven, CT:Yale University Press,153-92.

$\mathrm{Ku}$, Leighton. 2009b. "Health Insurance Coverage and Medical Expenditures of Immigrants and Native Born Citizens in the United States." American Journal of Public Health 99(7):132228.

$\mathrm{Ku}$, Leighton and Demetrios G. Papademtriou. 2007. "Access to Health Care and Health Insurance: Immigrants and Immigration Reform." In Securing the Future: US Immigrant Integration Policy, ed. Michael E. Fix. Washington D. C.: Migration Policy Institute.

$\mathrm{Ku}$, Leighton and Sheetal Matani. 2001. "Left Out: Immigrants' Access to Health Care and Insurance." Health Affairs 20(1):247-56.

LaVeist, Thomas. 2005. Minority Populations and Health: An Introduction to Health Disparities in the United States. San Francisco, CA: Jossey-Bass.

Leighley, Jan E. 2001. Strength in Numbers? The Political Mobilization of Racial and Ethnic Minorities. Princeton, NJ: Princeton University Press.

Lipsmeyer, Christine and Ling Zhu. 2011. "Immigration, Globalization, and Unemployment Benefits in Developed EU States.” American Journal of Political Science 55(3): 647-64.

Martin, Johnson. 2001. "The Impact of Social Diversity and Racial Attitudes on Social Welfare Policy.” State Politics \& Policy Quarterly 1(1):27-49.

Miguel, Edward and Mary Kay Gugerty. 2005. "Ethnic Diversity, Social Sanctions, and Public Goods in Kenya." Journal of Public Economics 89(11-12):2325-68.

Monogan, James E. III. 2013. "The Politics of Immigrant Policy in the Fifty U.S. States from 2005-2011.” Journal of Public Policy 33(1):35-64.

Nannestad, Peter. 2007. "Immigration and Welfare States: A Survey of 15 Years of Research." European Journal of Political Economy 23(2):512-32.

OECD. 2007. International Migration Outlook:SOPEMI 2007. Organization for Economic Cooperation and Development.

U.S. House of Representatives Committee on Way and Means. 1998. "Where Your Money Goes, Green book." Washington D.C.:Government Printing Office.

Pacheco, Julianna. 2011. "Using National Surveys to Measure State Public Opienion over Time: A Guideline for Scholars and An Application." State Politics \& Policy Quarterly 11(4): 415- 
39.

Potocky-Pripodi, Miriam. 2004. "Has Welfare Reform Created "Chilling Effects" for Refugees in the United States?" International Migration Review 38(4):1534-43.

Quinn, Kevin M. 2004. "Bayesian Factor Analysis for Mixed Ordinal and Continuous Responses.” Political Analysis 12(4):338-53.

Rowthorn, Robert. 2008. "The Fiscal Impact of Immigration on the Advanced Economics." Journal of Economic Policy 23(4):560-80.

Rocha, Rene, Daniel P. Hawes, Alisa Hicklin Fryar and Robert D. Wrinkle. 2014. "Policy Climate, Enforcement Rates, and Migrant Behavior: Is Self-Deportation a Viable Immigration Policy?” Policy Studies Journal 42(1): 79-100.

Rocha, Rene and Rodolfo Espino. 2010. "Segregation, Immigration, and Latino Participation in Ethnic Politics.” American Political Research 38(4): 614-35.

Rocha, Rene and Tetsuya Matsubayashi. 2013. "Latino Immigration and Representation in Local Politics." Urban Affairs Review 49(3):353-80.

Sanchez, Gabriel R. 2006. "The Role of Group Consciousness in Political Participation among Latinos in the United States." American Politics Research 34 (4): 427-50.

Schneider, Anne and Helen Ingram. 1993. "Social Constructions of Targeted Populations: Implications for Politics and Policy.” American Political Science Review 87(2): 334-47.

Starr, Paul. 2011. Remedy and Reaction: the Peculiar American Struggle over Health Care Reform. New Haven, CT: Yale University Press.

Soss, Joe and Sanford F. Schram. 2007. "A Public Transformed? Welfare Reform as Policy Feedback." American Political Science Review 101(1): 111-27.

Stichnothe, Holger and Karine Van der Straete. 2011. "Ethnic Diversity, Public Spending, and Individual Support for the Welfare State: A Review of the Empirical Literature." Journal of Economic Surveys 60(0):1-26.

Tolbert, Caroline and Rodney E. Hero. 2001. "Dealing with Diversity: Racial/Ethnic Context and Social Policy Change Dealing with Diversity: Racial/Ethnic Context and Social Policy Change." Political Research Quarterly 54(3):571-604.

Tomz, Michael, Jason Wittenberg and Gary King. 2003. "CLARIFY: Software for Interpreting and Presenting Statistical Results.” Journal of Statistical Software 8:1-30.

Tufte, Edward R. 1980. Political Control of the Economy. Princeton University Press.

Tumlin, Karen C., Wendy Zimmermann and Jason Ost. 1999. "State Snapshots of Public Benefits for Immigrants: A Supplemental Report to 'Patchwork Policies'." Urban Institute.

Waston, Tara. 2014. "Inside the Refrigerator: Immigration Enforcement and Chilling Effects in Medicaid Participation.” American Economic Journal: Economic Policy, forthcoming.

Zimmermann, Wendy and Michael Fix. 1998. "Declining Immigrant Applications for Medi-Cal and Welfare Benefits in Los Angeles County." Washington D.C.: the Urban Institute. 
Table 1: Determinants of Inequality in Medicaid Coverage Rates between Native- and ForeignBorn Populations

\begin{tabular}{|c|c|c|c|c|}
\hline Variable & $\begin{array}{l}\text { (1) Static } \\
D V: \Delta \text { Inequality } \\
\text { Coefficient }\end{array}$ & (PCSE) & $\begin{array}{l}\text { (2) ECM } \\
D V: \Delta \text { Inequality } t \\
\text { Coefficient }\end{array}$ & (PCSE) \\
\hline Immigration $_{\mathrm{t}}$ & $-0.226 * *$ & $(0.053)$ & -- & -- \\
\hline Eligibilityt & $-2.116^{* *}$ & $(0.510)$ & $-1.273^{* *}$ & $(0.365)$ \\
\hline Immigration $_{t} X$ Eligibility $_{t}$ & $0.095 * *$ & $(0.032)$ & -- & \\
\hline Inequality $_{\mathrm{t}-1}$ & -- & -- & $-0.614 * *$ & $(0.081)$ \\
\hline Immigration $_{\mathrm{t}-1}$ & -- & -- & $-0.161 * *$ & $(0.041)$ \\
\hline$\Delta$ Immigration & -- & -- & -0.192 & $(0.140)$ \\
\hline Immigration $_{\mathrm{t}-1} \mathrm{X}$ Eligibility & -- & -- & $0.051^{*}$ & $(0.022)$ \\
\hline$\Delta$ Immigration $\mathrm{X}$ Eligibility $_{\mathrm{t}}$ & -- & -- & $0.341 *$ & $(0.165)$ \\
\hline Ethnic Diversity & $8.572 * *$ & $(2.226)$ & $6.432^{* *}$ & $(1.519)$ \\
\hline Union Density & $-0.150 * *$ & $(0.050)$ & $-0.099 * *$ & $(0.033)$ \\
\hline Unemployment & $0.162 * *$ & $(0.067)$ & 0.066 & $(0.051)$ \\
\hline Poverty & $0.292 * *$ & $(0.081)$ & $0.182 * *$ & $(0.070)$ \\
\hline Mass Liberalism & -9.599 & (7.166) & -5.49 & $(5.835)$ \\
\hline Government Liberalism & $0.037 * *$ & $(0.015)$ & $0.028 *$ & $(0.012)$ \\
\hline Democratic Seat Share & $-5.623 * *$ & $(1.986)$ & $-3.896 * *$ & $(1.573)$ \\
\hline Democratic Governor & -0.429 & $(0.597)$ & -0.282 & $(0.503)$ \\
\hline Southern States & 0.015 & $(0.539)$ & 0.299 & $(0.376)$ \\
\hline Intercept & $3.634 *$ & $(1.749)$ & 2.210 & $(1.533)$ \\
\hline $\mathrm{N}$ & 594 & & 557 & \\
\hline $\mathrm{R}^{2}$ & 0.301 & & 0.335 & \\
\hline$\rho$ & 0.316 & & -- & \\
\hline
\end{tabular}

Significance levels: $*: 5 \%, * *: 1 \%$. 
Figure 1: Inequality in Medicaid Coverage between Foreign and Native Born Populations in 50 States, 1998-2010

Net-Difference in Medicaid Coverage Rates between Native and Foreign Born Population
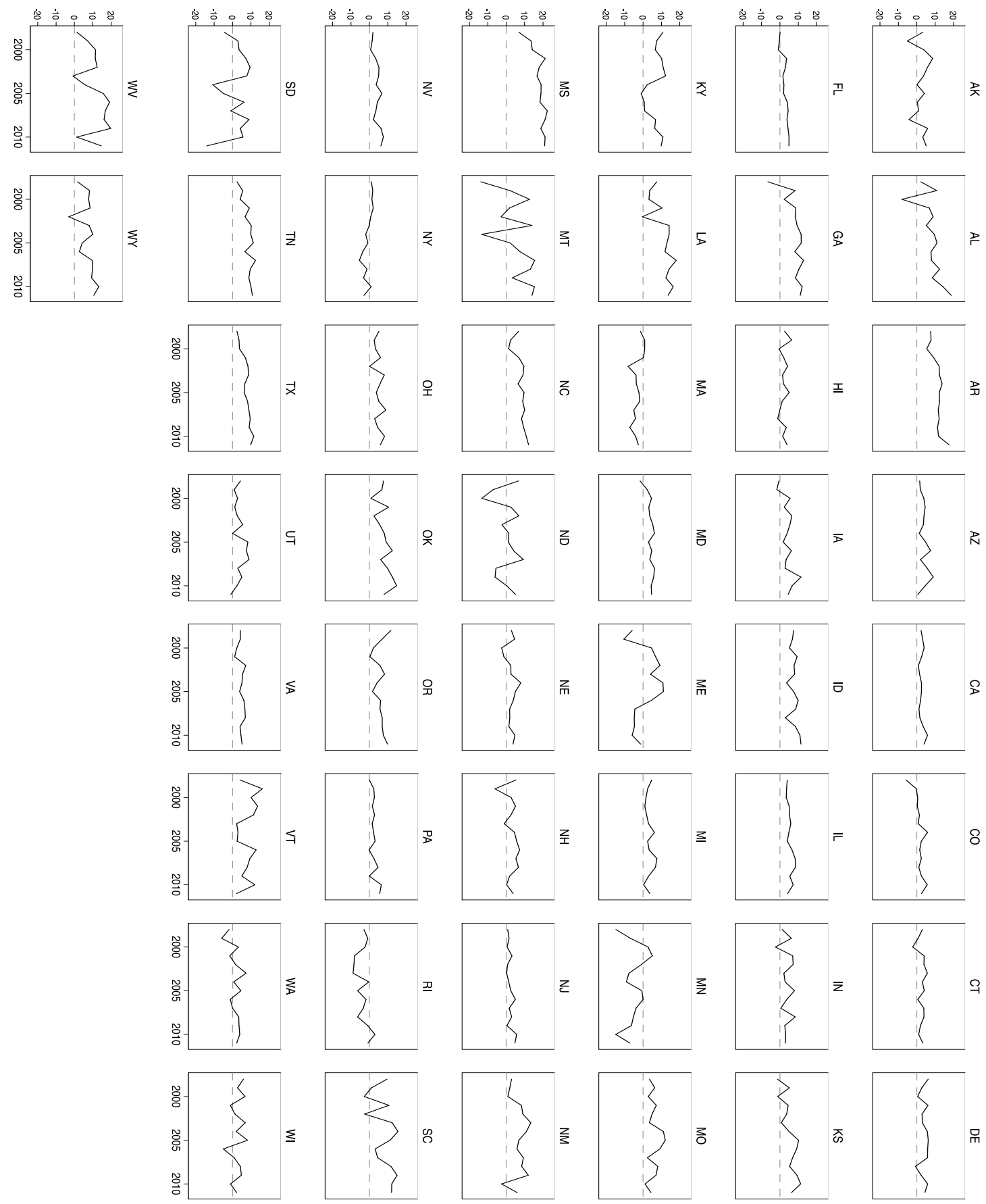
Figure 2: Ranking Fifty States based on the Mean Inequality Score (Average Net Difference in Medicaid Coverage Rates between Foreign and Native Born Populations from 1998 to 2010)

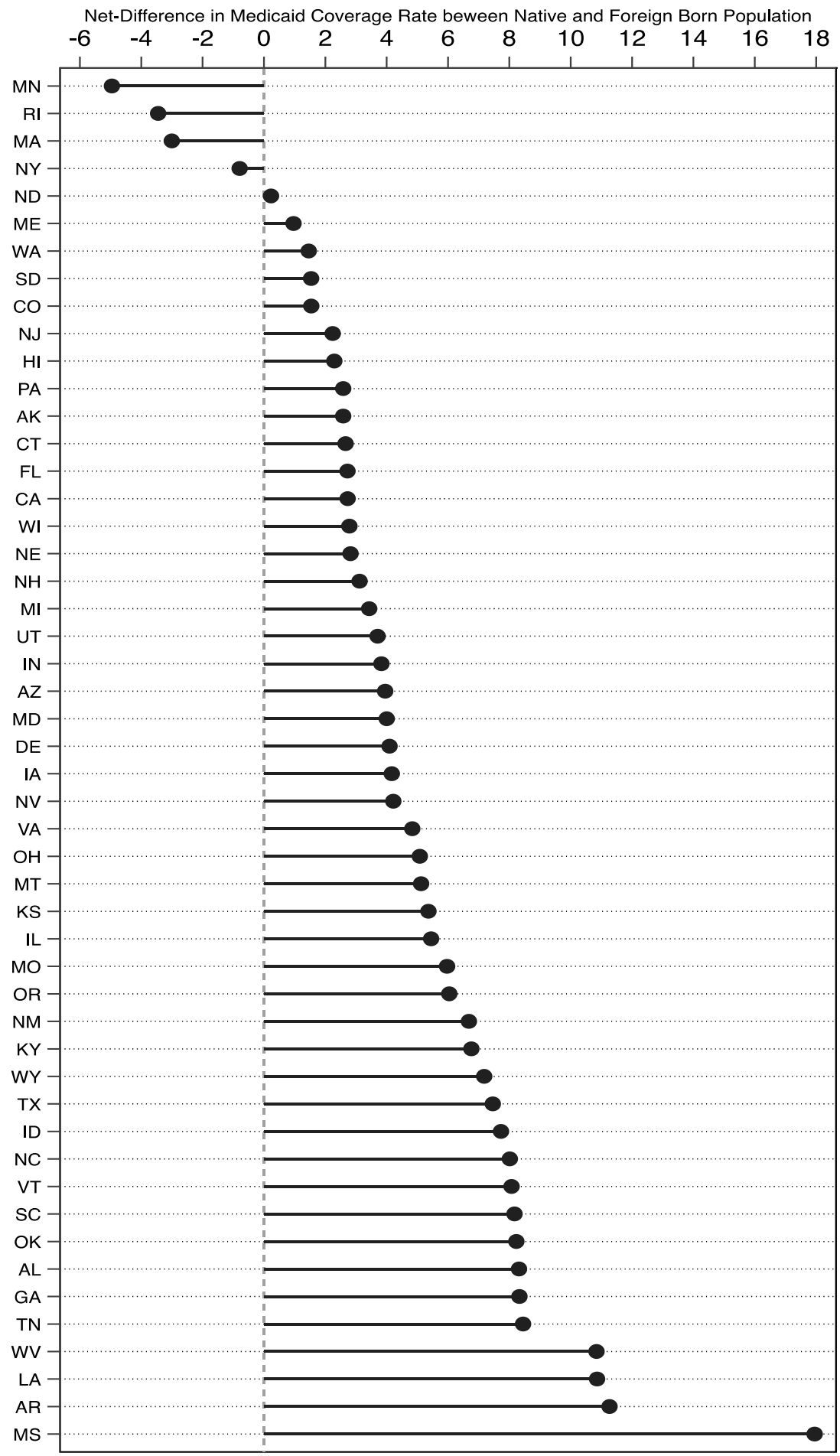


Figure 3: Ranking Fifty States based on the Mean Level of Immigrant Inclusiveness in Medicaid (Average Immigrant Medicaid Eligibility Score from 1998 to 2010)

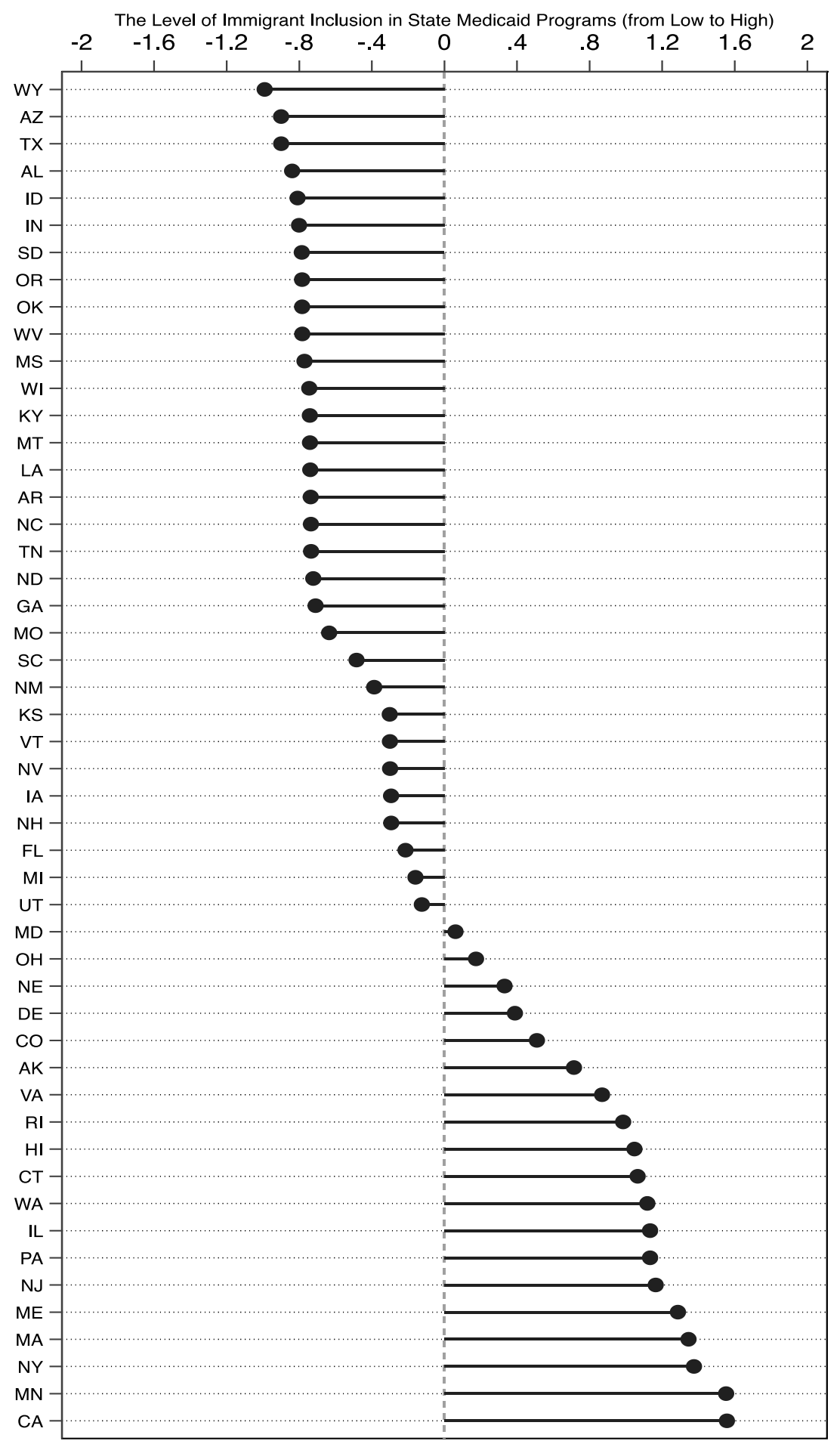


Figure 4: Comparing the Marginal Effect of State Policy Conditional Upon Immigration Population Density

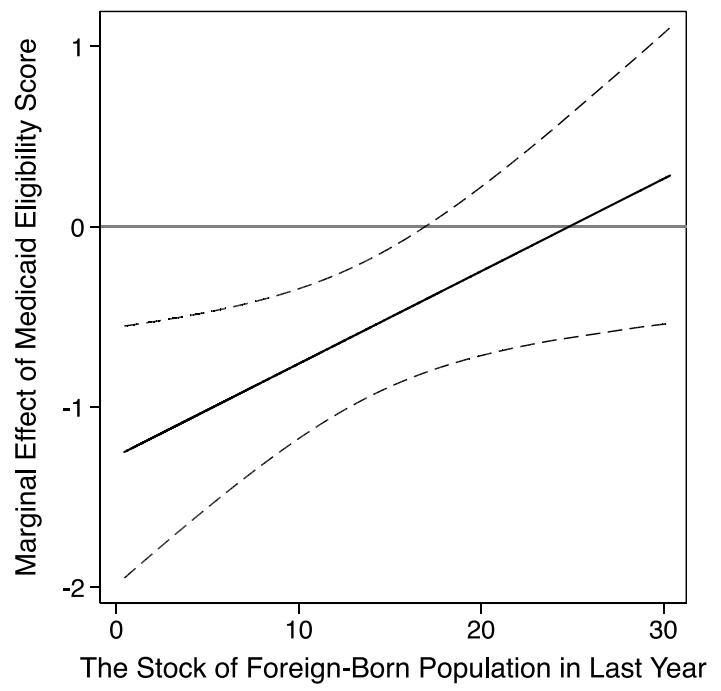

(a) The Marginal Effect of Immigrant Medicaid Eligibility Score Conditional Upon Immingration Im-1

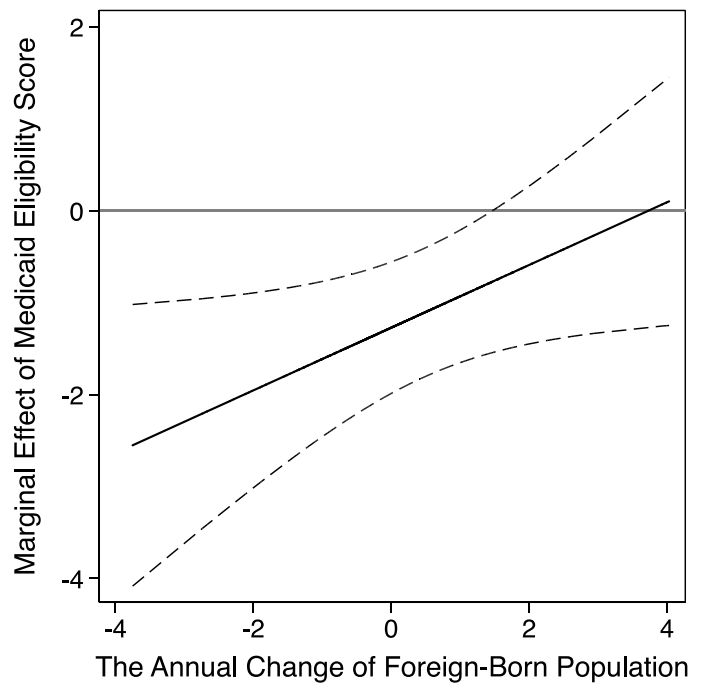

(b) The Marginal Effect of Immigrant Medicaid Eligibility Score Conditional Upon $\Delta$ Immigration 
Figure 5: Comparing the Short-Run Effects of Immigration on Medicaid Coverage Gap between Native- and Foreign-Born Population in States with Inclusive and Exclusive Medicaid Policies

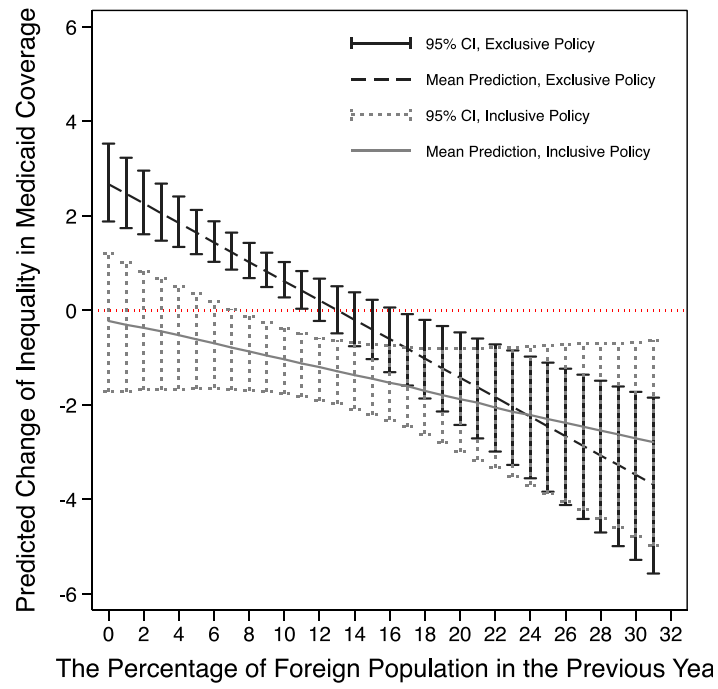

(a) The Immediate Changes in Inequality Associated with Immingration Im 1

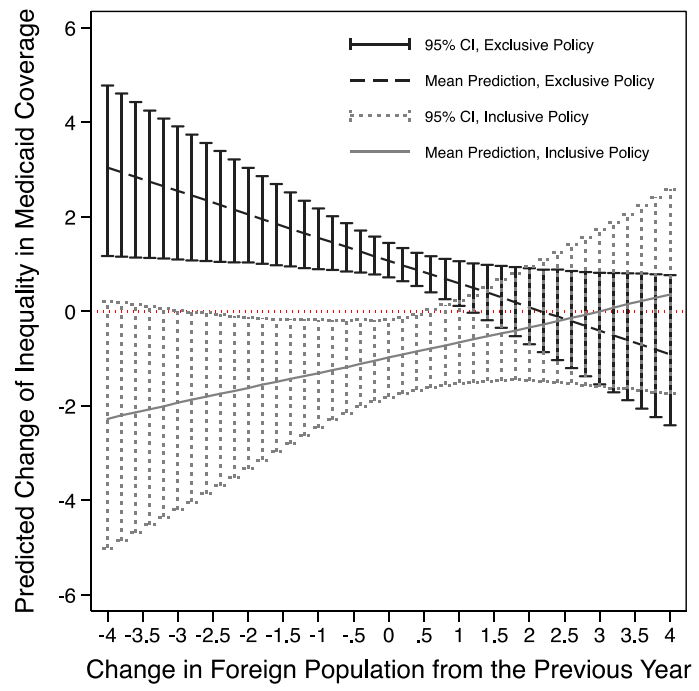

(b) The Immediate Changes in Inequality Associated with $\Delta$ Immigration 
Figure 6: Comparing the Long-Run Effects of Immigration on Medicaid Coverage Gap between Native- and Foreign-Born Population in States with Inclusive and Exclusive Medicaid Policies

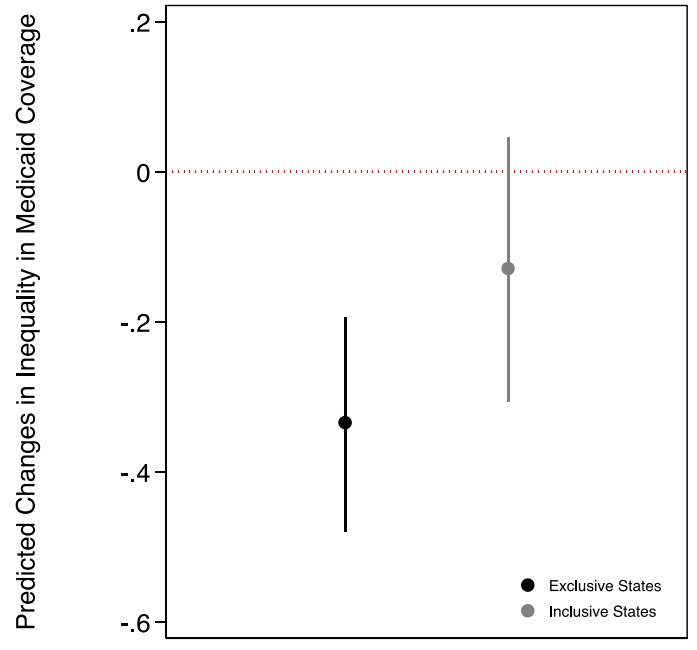

(a) Estimated Long-Run Effects

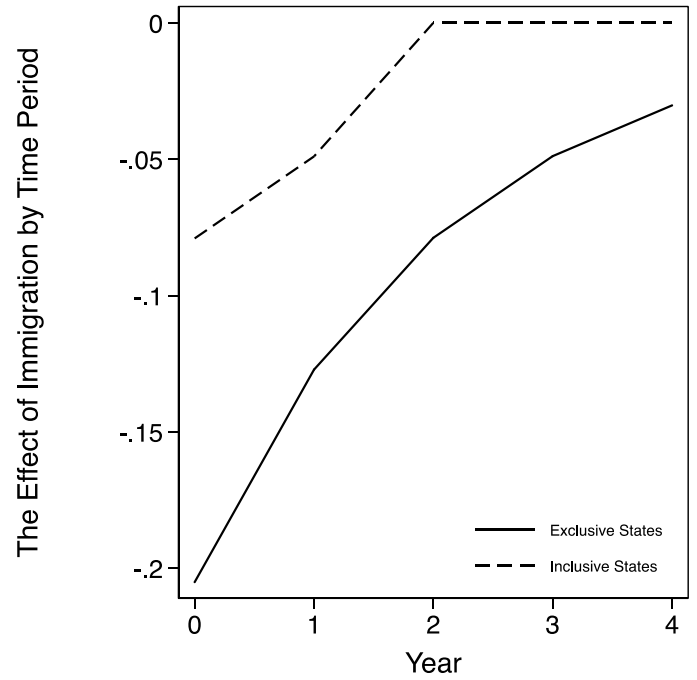

(b) Estimated Lag Distributions of the Impact of Immigration 